\title{
Structure valve degeneration in new bioprosthesis: New concerns and valve-in-valve (VIV) bailout
}

\author{
Richard J. Shemin, MD
}

\footnotetext{
From David Geffen UCLA School of Medicine and Division Cardiac Surgery, Department of Surgery, and Cardiovascular Center, Ronald Regan UCLA Medical Center, Los Angeles, Calif. Disclosures: Author has nothing to disclose with regard to commercial support.

Received for publication Aug 11, 2016; accepted for publication Aug 15, 2016; available ahead of print Sept 23, 2016.

Address for reprints: Richard J. Shemin, MD, Ronald Reagan UCLA Medical Center, David Geffen School of Medicine at UCLA, 100 UCLA Medical Plaza, Suite 730, Los Angeles, CA 90095 (E-mail: Rshemin@ mednet.ucla.edu).

J Thorac Cardiovasc Surg 2016;152:1638

$0022-5223 / \$ 36.00$

Copyright (C) 2016 by The American Association for Thoracic Surgery

http://dx.doi.org/10.1016/j.jtcvs.2016.08.025
}

Bioprosthetic valves in current use have well-known and very acceptable tissue durability. Tissue failure is multifactorial. Stress on the leaflets is in part a cause of tissue degeneration. Decades have been spent perfecting the incorporation of tissue into the valve stent housing and using strut material with "spring" properties to reduce the tissue load during leaflet closure.

Now we have the same tissue mounted into transcatheter aortic valve replacement (TAVR) valves and self-expanding sutureless aortic bioprostheses. Leaflet function can be determined in vitro and in vivo within a short period of time; however, these new valve designs are mounting the leaflet tissue to stents and present a different stress pattern that can lead to premature calcification and leaflet degeneration. It takes years to study these adverse events. Because these devices are used in lower-risk and younger patients, the clinical concerns shift from feasibility and function to durability.

In this issue of the Journal, Amable and colleagues ${ }^{1}$ report a TAVR, valve-in-valve (VIV) treatment strategy, for 5 failed self-expanding sutureless (Perceval; LivaNova PLC, London, United Kingdom) aortic valves. A VIV treatment strategy for the Perceval valve carries concern regarding adequate fixation and valve stability as well as paravalvular leak. Another concern of VIV procedures is the prosthetic gradient and patient prosthesis mismatch. The 5 prostheses reported in this series were treated with self-expanding TAVR valves. Early gradients were as high as $32 \mathrm{~mm} \mathrm{Hg}$ (mean) and at 30 days decreased by $10 \mathrm{~mm}$ $\mathrm{Hg}$ (mean). There was only mild residual regurgitation.

These case reports serve as alerts to new problems we may face. Future data and experience will help us concerns.

\section{Reference}

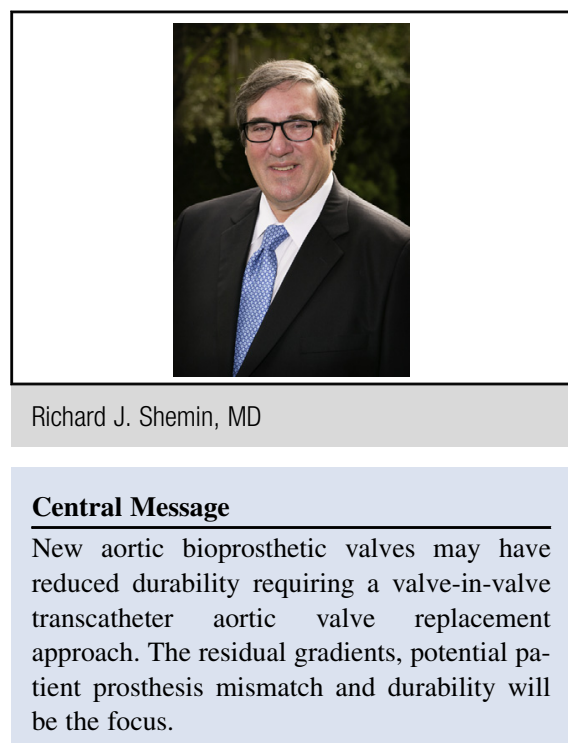

See Article page 1635.

understand the durability of TAVR valves, the Perceval valve, and future bioprosthetic tissue valves with tissue mounted within stents. When these valves fail from tissue degeneration, the next best valve therapy will be a VIV strategy. The best VIV device is not known. The self-expanding device worked well in this series, but valve gradients and patient prosthesis mismatch are real

Data are mounting that VIV treatment of failed surgically implanted bioprosthesis will result in residual valve gradients. Thus, the initial surgical valve must have the largest annular size for each patient to accommodate a potential VIV therapy. The strategy of annular enlarged to accommodate a larger bioprosthesis in large (body mass index) young patients with a small annulus is prudent if future VIV procedures are predicted.

1. Amable N, Zannis K, Veugeois A, Caussin C. Early outcome of degenerated selfexpandable sutureless aortic prostheses treated with transcatheter valve implantation: a pilot series. J Thoracic Cardiovasc Surg. 2016;152:1635-7. 